\title{
AIDS VACCINE AND RAPID DIAGNOSTIC TO CLINIC
}

Combatting AIDS. Biotechnology is continuing to play the key role in the fight against acquired immune deficiency syndrome (AIDS). In recent developments, MicroGeneSys (West Haven, CT) became the first to gain U.S. Food and Drug Administration (FDA) approval to test its experimental vaccine against AIDS. The vaccine, "VaxSyn HIV-1," is based on recombinant versions of an AIDS virus surface antigen produced via insect cell culture.

On the diagnostic front, Cambridge Bioscience Corp. (Worcester, MA) received the nod from FDA to begin testing its "Recombigen" rapid latex agglutination assay that uses a genetically engineered protein to detect antibodies produced in response to the AIDS virus. Also, Eastman Kodak (Rochester, NY) said it will soon file for FDA approval to begin clinical studies on a new test developed by Cellular Products (Buffalo, NY) that detects both AIDS and adult T-cell leukemia/lymphoma (caused by HTLV-I). The test will be marketed as part of Kodak's business arrangement with Cetus (Emeryville, CA).

More testing. Immunomedics (Newark, $\mathrm{NJ}$ ) received FDA permission to begin multi-center trials of a new radioimmunodetection kit to image colorectal cancer. The assay involves injecting radioactive antibodies that bind to a colorectal cancer marker called carcinoembryonic antigen (CEA). Also, Pharmatec (Gainesville, FL) will begin human testing of its patented "carrier" attached to the female sex hormone estradiol in the treatment of several female hormonal conditions.

And on the agricultural side, DNA Plant Technology Corp. (DNAP, Cinnaminson, NJ) announced that a monoclonal antibody-based kit to detect phytophthora disease is being tested in saybeans, citrus, and other crops. The kit was developed by AgriDiagnostics Associates, DNAP's joint venture with Koppers (Pittsburgh, PA), under an R\&D contract with Ciba-Geigy Corp. (Ardsley, NY).

More lawsuits. Enzo Biochem (New York, NY) has charged Johnson \& Johnson (New Brunswick, NJ) with unfair competition and breach of contract over the development, mar- keting, and manufacture of DNA probe diagnostics. Enzo is seeking $\$ 100$ million in compensation and $\$ 500$ million more in punitive damages, claiming that J\&J prevented Enzo from pursuing commercial opportunities, has only developed one of the probes Enzo supplied, and has refused to pay Enzo $\$ 3$ million it owes.

In another suit, Centocor (Malvern, PA) is seeking relief from interference by Cetus in an exclusive license agreement between Centocor and Velos Group (Bethesda, MD) covering patent applications for the production and use of monoclonal antibodies against the endotoxin core of Gram negative bacteria. Cetus is already suing Velos in an effort to obtain the license to Velos' patent rights.

Probe patents. Enzo Biochem and Integrated Genetics (Framingham, MA) have new patents on DNA probe technology. Enzo's patent, exclusively licensed from Yale University (New Haven, CT), covers a non-radioactive technology that increases signal detection 10-100 times over current non-isotopic methods. Integrated's patent covers the use of all DNA probes to detect the presence of Salmonella-specific DNA in food and clinical samples. The patent was exclusively licensed to Gene-Trak Systems, a joint venture between Integrated and Amoco Corp. (Chicago, IL).

New chairman at Molecular. Kenneth F. Tempero, formerly senior vice president of $R \& D$ at $G$. D. Searle (Skokie, IL), has become chairman and chief executive officer of Molecular Genetics (Minnetonka, MN). These positions had been vacant since the November 1986 resignation of cofounder Franklin Pass.

Financing. The public equity market hasn't quite dried up yet for biotech concerns: Cell Technology Inc. (Boulder, CO), which emphasizes immunotherapy, went public with an offering of 1 million units at $\$ 8$ each. Meanwhile, Gen-Probe (San Diego, CA) is planning an initial public offering (IPO) of 2.5 million shares priced between $\$ 9$ and $\$ 11$ each, and Invitron (St. Louis, MO) has regis- tered for a 3-million-share IPO at \$11-13 per share. Also, in a recent private placement, BioStar Medical Products (Boulder, CO) raised $\$ 3.6$ million.

New ventures. Hazleton Laboratories Corp. (Vienna, VA), Virginia's Center for Innovative Technology, Rocco Investors, and Binax Corp. have formed a new company called ProScience Corp. (Vienna, VA) to develop rapid diagnostics and therapeutics for agricultural animals. First up are products to detect Staphylococcus aure$u s$-caused mastitis in dairy cattle and antibiotic residues in milk. BiotechInternational Consultants (San Francisco, CA) now offers consulting services for conversion of microbial fermentation equipment into mammalian cell culture bioreactors. And a new university-industry consortium at the University of Wiscon$\sin$ (Madison) will focus on the use of organisms and biochemical processes to produce specialty chemicals.

New agreements involving biotech companies:

- Biostar Medical Products (Boulder, CO) and C. Itoh (Osaka) signed a joint marketing agreement for the distribution of BioStar's diagnostics in Japan. (For an in-depth analysis of U.S.-Japanese partnerships in biotech, see this month's special section on "Doing Business with Japan.")

- G. D. Searle entered into an agreement with Invitron for the development, manufacture, and commercialization of azurophil-derived bactericidal factor, a broad-spectrum anti-microbial protein.

- Liposome Technology Inc. (Menlo Park, CA) will study the feasibility of developing a liposome-based delivery system to administer the bronchodilator terbutaline for Sweden's AB Draco.

- Biotechnology Development Corp. (Newton, MA) and Immune Response Corp. (La Jolla, CA) will commercialize a new experimental AIDS vaccine developed by Jonas Salk.

- International Agritech Resources (New York, NY) will help Genetic Diagnostics Corp. (Great Neck, NY) in the formation of an animal health division to focus on diagnostic and therapeutic products. 